\title{
Effect of dental adhesives on the exudative phase of the inflammatory process in subcutaneous tissue of rats
}

\section{Efeito dos adesivos dentais na fase exsudativa do processo inflamatório em tecido subcutâneo de ratos}

\author{
Halim Nagem-Filho* \\ César Roberto Monteiro** \\ Haline Drumond Nagem*** \\ José Luiz Lage-Marques ${ }^{* * * *}$
}

\begin{abstract}
The vascular changes in the subcutaneous connective tissue of rats induced by dentin bonding systems (one step) was studied and compared to those induced by saline solution (negative control) and Furacin (positive control), during the exudative phase of the inflammatory process. Twenty $\mathrm{mg} / \mathrm{kg}$ of Evan's blue were injected intravenously in the vein of the rats' penises; $0.1 \mathrm{ml}$ of each substance tested was inoculated in the subcutaneous tissue. After a 3 hour period the animals were sacrificed and their skins were excised and punched out with a standard steel $2.5 \mathrm{~cm}$ in diameter. The specimens were immediately immersed in $8 \mathrm{ml}$ of formamide and taken to a double boiler for 72 hours at $37^{\circ} \mathrm{C}$, to remove the dye. The liquid containing the overflowed dye was filtered, analyzed in the spectrophotometer $(620 \mathrm{~nm})$ and classified according to the criteria established by Nagem-Filho, Pereira (1976). After statistical analysis, the irritative potential of the substances was ranked as follows: Furacin (severe) > Single Bond and Bond 1 (moderate - no significant differences between the dentin bonding systems tested) > saline solution (not significant as regards the irritation degree).
\end{abstract}

DESCRIPTORS: Dentin-bonding agents; Capillary permeability.

RESUMO: Estudaram-se as alterações vasculares do tecido conjuntivo subcutâneo de ratos induzidas por sistemas adesivos dentinários (único passo), comparados com solução fisiológica (controle negativo) e Furacin (controle positivo), durante a fase exsudativa do processo inflamatório. Com esse propósito, injetaram-se intravenosamente, na veia do pênis de ratos, $20 \mathrm{mg} / \mathrm{kg}$ de peso corporal de "Evan's blue", e no tecido subcutâneo inoculou-se 0,1 ml de cada substância a ser analisada. Após intervalo de três horas os animais foram sacrificados, suas peles excisadas e recortadas com perfurador de 2,5 cm de diâmetro. As peças foram imersas imediatamente em oito ml de formamida e levadas ao banho-maria a $37^{\circ} \mathrm{C}$, por 72 horas, para remoção do corante. O líquido contendo o corante extravasado foi filtrado, analisado no espectrofotômetro $(620 \mathrm{~nm})$ e classificado segundo os critérios estabelecidos por Nagem-Filho, Pereira (1976). O potencial irritativo dos produtos, após análise estatística, se apresentou em ordem decrescente: Furacin (considerado como grau de magnitude severo) > Single Bond e Bond 1 (que se mostraram significamente similares, classificados como moderados) > soro fisiológico (comportando-se como não-significante quanto ao grau de irritação).

DESCRITORES: Adesivos dentinários; Permeabilidade capilar.

\section{INTRODUCTION}

The longevity of a composite restoration depends on a low viscosity resin that is capable of penetrating intimately and polymerizing in the tooth structures (e.g. enamel and dentin) (Carvalho $\left.^{2}, 1998\right)$.

Several chemical components have been used to formulate dental adhesive systems in order to improve their mechanical and physical properties (Eliades et al. $\left.{ }^{7}, 1999\right)$. Although bond strength and other relevant properties have been widely investigated in the last decades, just recently researchers have aimed to evaluate the biocompatibility of the adhesive systems and/or each of their components separately. Despite great progress in the production of new dental polymers, the application of these products is still controversial (Ivanyi et $\left.a l .{ }^{12}, 2002\right)$. Due to the wide number of products available in the marketplace, as well as the variety of techniques indicated for their clinical application, it has been difficult to predict the biological

\footnotetext{
*Professor, Chairman; **MSc, Professor - School of Dentistry, Taubaté University.

***PhD, Professor - School of Dentistry of Bauru, Sagrado Coração University.

$* * * *$ Adjunct Professor, School of Dentistry, University of São Paulo.
} 
Nagem-Filho H, Monteiro CR, Nagem HD, Lage-Marques JL. Effect of dental adhesives on the exudative phase of the inflammatory process in subcutaneous tissue of rats. Pesqui Odontol Bras 2003;17(2):109-12.

aggressiveness potential of these products on the pulp tissue (Costa et al. ${ }^{4}, 1999$ ).

Costa et al. ${ }^{5}$ (1997) evaluated the histological response of rat connective tissue after the application of All Bond and Scothbond MP. Under microscope examination, the results for both adhesives indicated a very high inflammatory reaction with mostly mononuclear cells around the tubules, and also wide areas of collagen degradation and exudation. After a period of time, all histological characteristics went back to normal. Other methods (Geurtsen $\left.{ }^{9}, 2000\right)$ involve the implantation of the material into the connective tissue of rats to evaluate the histopathologic characteristics (Menezes, Nagem-Filho, Valle $\left.{ }^{16}, 1982\right)$ or the vascular permeability changes in plasmatic exudation (NagemFilho et al. $\left.{ }^{17}, 1999\right)$.

Due to the limited availability of information in literature about the effect of dental adhesive systems on the initial phases of the inflammatory process, this study aimed to evaluate the irritative potential of some adhesive systems, by studying the vascular changes during the exudative phase of the inflammatory process in connective tissue of rats.

\section{MATERIALS AND METHODS}

Two one-step adhesive systems (Bond 1, Dentsply Indústria e Comércio Ltda., Petropólis, Rio de Janeiro, Brazil - GI; Single Bond, 3M do Brasil, Sumaré, São Paulo, Brazil - GII) were evaluated. Fifteen rats $(250 \mathrm{~g})$ were anesthetized with ethyl ether and dorsally shaved. After 2 hours, the animals were reanesthetized, a 2\% Evan's blue staining solution was injected intravenously, $20 \mathrm{mg} / \mathrm{kg}$, and the adhesive systems were injected in the subcutaneous connective tissue of the rats. Injections of Furacin (GIII) and physiological saline (GIV) formed the positive and negative control groups, respectively.

After 3 hours, the animals were sacrificed and had their dorsal skins excised, cut at the limits of the bluish halos and reduced to small fragments. These fragments were immersed in $6 \mathrm{ml}$ of formamide for 72 hours at $37^{\circ} \mathrm{C}$. Tubes for spectrophotometer analysis were filled with the filtered supernatant liquid. The data for optical density were submitted to analysis of variance $(p<0.05)$ and the means were compared by the Tukey test. Additionally, the exudation level was classified as non-significant, discrete, moderate or intense (Nagem-Filho et al. $\left.{ }^{17}, 1999\right)$.

\section{RESULTS}

The means and standard deviations for optical density values of each group are presented on $\mathrm{Ta}$ ble 1 . The Tukey test showed a statistically significant difference between the controls GIII and GIV. A statistically significant difference was detected between GI and GII $(\mathrm{p}<0.05)$, which did differ from the controls $(\mathrm{p}>0.05)$.

According to the exudation level, groups were ranked from the most to the least aggressive response as GIII-GII-GI-GIV. Such results concord with the optical density means.

\section{DISCUSSION}

The adhesive systems tested in this study have acetone or ethanol as solvents. Both chemicals are efficient bactericidal agents of immediate activity by reducing the superficial tension of the bacterial membrane. Acetone improves the diffusion of the primer/adhesive by reducing dentin tension, but all of the dentin bonding agents were found to be cytotoxic following the quantitative technique at 24 and 72 hours. (Koliniotou-Koubia et al. ${ }^{14}$, 2001). In spite of its inherent toxicity, the aggressive potential of acetone is controversial due to its high and fast volatilization (Finger, Balkenhol ${ }^{8}$, 1999). The results of the study by Ivanyi et al. ${ }^{12}$ (2002) suggest that dental bond materials applied on a very thin layer of dentin may affect the blood supply to the dental pulp. However, the authors could not demonstrate any statistical difference between the vasodilatation caused by the acetone-containing and the acetone-free bond materials. Differences in pulp irritative responses of acetone applied directly to the connective tissue or in teeth may exist because the dentin probably acts as a protective barrier in the latter.

Hygroscopic substances as alcohol absorb dentin humidity, leading to desiccation of its substrate. As a result, centrifugal flow of fluids is

TABLE 1 - Means and standard deviations (SD) for optical density.

\begin{tabular}{c|c}
\hline \hline Groups & Mean (SD) \\
\hline GI & $0.436(0.061) \mathrm{b}$ \\
\hline GII & $0.458(0.055) \mathrm{b}$ \\
\hline GIII & $1.098(0.052) \mathrm{a}$ \\
\hline GIV & $0.07(0.010) \mathrm{c}$ \\
\hline
\end{tabular}

Means followed by the same label are not different $(\mathrm{p}>0.05)$. 
Nagem-Filho H, Monteiro CR, Nagem HD, Lage-Marques JL. Effect of dental adhesives on the exudative phase of the inflammatory process in subcutaneous tissue of rats. Pesqui Odontol Bras 2003;17(2):109-12.

formed inside dentin tubules, so that odontoblasts are sucked into the odontoblastic extension causing cellular injuries (Perdigão et al. ${ }^{18}, 2001$ ). Solvents have the ability of extracting water from demineralized surfaces. As it is emphasized in the current concepts of adhesion, water plays an important role in order to facilitate the penetration of adhesives into dentin substrates (Kanca III ${ }^{13}$, 1992; Gwinnett ${ }^{10}$, 1992).

Besides, it has a very high miscibility in organic solvents and both are quickly spread through the collagen network, preventing the collagen fibers from collapsing, reducing surface porosities and allowing deeper penetration of the primer's resinous monomers into dentinal tissues to form a continuous hybrid zone (Carvalho², 1998).

However, when dentin surface humidity is somewhat excessive, a process called "overweting" could take place, in which molecules of the resinous agents get split and then aggregate to produce micelles that accumulate on the surface, causing less diffusion of adhesives through the collagen fibers, which results in poor adhesion and sealing. (Tay et al. $\left.{ }^{20}, 1996\right)$.

An important process for achieving successful resin restorations is the use of one-step dentin adhesive systems. Thus, it is crucial to analyze the biocompatibility of each bonding agent in order to have a better understanding of its behavior since they tend to get an intimate contact with the pulp dentin complex. Most of the primers contain alcohol or acetone as solvents. These substances can be aggressive to cells and odontoblastic extensions due to their potential of extracting lipids from plasmatic membranes (Ciucchi, Bouillaguet ${ }^{3}$, 1995).

Besides irritating the odontoblasts, the high diffusibility of the volatile primers combined with their irritative potential can also irritate other pulpal connective tissue cells (Ciucchi, Bouillaguet $^{3}$, 1995). As mentioned before, it was expected that the primer/adhesives containing acetone or alcohol would act as irritating substances when in contact with the connective tissue of rats.

There is a great divergence in the literature regarding the biocompatibility of dental adhesive systems. While some authors have not shown toxicity of adhesive monomers, others have demonstrated the toxicity of such chemicals like HEMA and BISGMA (Bouillaguet et al. $\left.{ }^{1}, 1996\right)$. Hanks et $a l .{ }^{11}$, (1992), have stated that the molecular weight of BISGMA is 512.65; TEGMA, 286.36; HEMA, 130.14 and UDMA 496.69, suggesting that when adhesives with those components are applied on dentin, HEMA will show the highest cytotoxic effect due to its low molecular weight, allowing a faster interdiffusion through dentin compared to bigger resin molecules which are basically insoluble in water. As a consequence, higher concentration of these substances could reach pulp tissues. Therefore, it may be correct to think that the irritative potential of adhesive resins applied directly to dentin does not depend only on the cytotoxic potential of their components, but also on their interdiffusion ability through dentin tubules. In this study, the adhesive systems Bond 1 and Single Bond stimulated a moderate exudative activity when in contact with the connective tissue of rats, showing that the severity of the inflammatory process would regress to an acceptable state (Costa et al. $\left.{ }^{6}, 2000\right)$. Such statement elucidates that the intensity of the inflammatory process might be linked to the initial levels of edema. Ratanasathien et al. ${ }^{19}$ (1995) classified the dentin adhesive systems based on their cytotoxic effects after 24 and 48 hours in fibroblast culture, as follows: BISGMA > UDMA >> TEGMA >>> HEMA. $\operatorname{Kurata}^{15}(1998)$ evaluated the interaction between the combined effects of the monomers. According to the author, monomers (e.g. HEMA) that show lower toxicity compared to the others can act as diluents for the most viscous and hydrophobic monomers, such as BISGMA, thus diminishing their irritating potential. Therefore, clinicians should understand carefully the properties of the adhesive system currently used, should be able to analyze the dentin substrate which they are working on, and also have the know-how to apply the chosen technique in order to achieve optimal results.

\section{CONCLUSION}

It was concluded that monomers become irritative only when they are in an intimate contact with pulp or connective tissues. The irritative potential of Single Bond and Bond 1 is moderate and there were no significant differences between the dentin bonding systems tested. 
Nagem-Filho H, Monteiro CR, Nagem HD, Lage-Marques JL. Effect of dental adhesives on the exudative phase of the inflammatory process in subcutaneous tissue of rats. Pesqui Odontol Bras 2003;17(2):109-12.

\section{REFERENCES}

1. Bouillaguet S, Wataha JC, Hanks C, Ciucchi B, Holz J. In vitro cytotoxicity and dentin permeability of HEMA. J Endod 1996;22:244-8.

2. Carvalho RM. Adesivos dentinários: fundamentos para aplicação clínica. Rev Dent Restauradora 1998;1:96.

3. Ciucchi B, Bouillaguet S. Adhesion in restorative dentistry. In: Proceedings of the International Symposium, Bologna; 1995.

4. Costa CA, Vaerten MA, Edwards CA, Hanks CT. Cytotoxic effects of current dental adhesive systems on immortalized odontoblast cell line. Dent Mater 1999; 15:434-41.

5. Costa CA de S, Hebling J, Teixeira MF. Estudo preliminar da compatibilidade biológica dos adesivos dentinários All-Bond 2 e Scotchbond MP. Avaliação histológica de implantes subcutâneos em ratos. Rev Odontol Univ São Paulo 1997;11:11-8.

6. Costa CA de S, Hebling J, Hanks CT. Current status of pulp capping with dentin adhesive systems: a review. Dent Mater 2000;16:188-97.

7. Eliades G, Vougiouklakis G, Palaghias G. Effect of dentin primers on the morphology, molecular composition and collagen conformation of acid-demineralized dentin in situ. Dent Mater 1999;15:310-7.

8. Finger WJ, Balkenhol M. Practitioner variability effects on dentin bonding with an acetone-based one-bottle adhesive. J Adhes Dent 1999;1:311-4.

9. Geurtsen W. Biocompatibility of resin-modified filling materials. Crit Ver Oral Biol Med 2000;11:333-55.

10. Gwinnett AJ. Moist versus dry dentin: Its effect on shear bond strength. Am J Dent 1992;5:127-9.
11. Hanks CT, Wataha JC, Parsell RR, Strawn SE. Delineation of cytotoxic concentrations of two dentin-bonding agents in vitro. J Endod 1992;18:589-96.

12. Ivanyi I, Balogh AE, Fazekas A, Rosivall L, Nyarasdy I. Comparative analysis of pulpal circulatory reaction to an acetone-containing and an acetone-free bonding agent as measured by vitalmicroscopy. Oper Dent 2002;27:367-72.

13. Kanca III J. Resin bonding to wet substrate. I. Bonding to dentin. Quintessence Int 1992;23:39-41.

14. Koliniotou-Koubia E, Dionysopoulos P, Koulaouzidou E, Kortsaris A.H. In vitro cytotoxicity of six dentin bonding agents. J Oral Rehabil 2001;28:971-5.

15. Kurata S. Tomorrow's dental resins monomers. Bull Kanagawa Dent Coll 1998;26:92-7.

16. Menezes MSS, Nagem-Filho H, Valle AL. Biocompatibilidade dos vernizes cavitários, convencional e modificado, no tecido subcutâneo do rato. Ciência, Cultura e Saúde 1982;4:27-30.

17. Nagem-Filho H, Dias AR, Aragão HDN. Potencial irritativo dos sistemas adesivos. Salusvita 1999;18:43-51.

18. Perdigão J, Carmo AR, Geraldeli S, Dutra HR, Masuda MS. Six-month clinical evaluation of two dentin adhesives applied on dry $v$ s. moist dentin.

19. Ratanasathien S, Wataha JC, Hanks CT, Dennison JB. Cytotoxic interative effects of dentin bonding components on mouse fibroblasts. J Dent Res 1995;74:1602-6.

20. Tay FR, Gwinnett AJ, Wei SHY. The overwet phenomenon: a transmission electron microscopic study of surface moisture in the acid-conditioned, resin-dentin interface. Am J Dent 1996;9:161-6.
Recebido para publicação em 04/06/02 Enviado para reformulação em 26/03/03 Aceito para publicação em 28/04/03 